\title{
PKM Pelatihan Penulisan Karya Tulis Ilmiah Bagi Guru Sekolah Dasar Kecamatan Situbondo di SD Islam Al Abror
}

\author{
Nur Holifatuz Zahro ${ }^{1}$ \\ 1) Universitas Abdurachman Saleh Situbondo \\ holifatuzzahro@gmail.com
}

\begin{abstract}
ABSTRAK: Kegiatan PKM ini dilakukan pada Lembaga Sekolah Dasar di Kelurahan Patokan Kec.Situbondo yaitu di SDI Al-Abror sebagai mitra. Kegiatan ini dimaksudkan untuk memotivasi dan melatih para guru di sekolah tersebut agar mau melaksanakan kegiatan penelitian dan mau menulis karya tulis ilimah secara berkesinambungan. Rancangan mekanisme pelaksanaan kegiatan PKM ini dilakukan dengan mengadopsi langkah-langkah action research yang terdiri dari 4 (empat) tahapan, yaitu: perencanaan, tindakan, observasi dan evaluasi, dan refleksi. Kegiatan-kegiatan atau aktivitas-aktivitas dari masing-masing tahapan yaitu (1) Perencaanaan, pada tahap ini dilakukan koordinasi awal antara tim pengusul program kemitraan bersama tim sekolah mitra untuk mengidentifikasi permasalahan yang ada, analisis kebutuhan mitra, dan analisis potensi sekolah, selanjutnya disusun program pelatihan, (2) Pelaksanaan Tindakan, Tindakan dalam kegiatan ini berupa implementasi Program. Kegiatan-kegiatan yang dilakukan dalam implementasi program meliputi; pembentukan Tim Pelaksana, dan pelaksanaan Workshop Karya Tulis Ilmiah, (3) Observasi dan Evaluasi, Observasi dilakukan terhadap proses pembuatan karya tulis ilmiah (KTI) dan Jurnal Ilmiah oleh para guru mitra. Instrumen yang digunakan berupa catatan lapangan, tahapan akhir yaitu (4) Refleksi, Refleksi dilakukan terhadap kegiatan yang telah dilaksanakan.
\end{abstract}

Kata kunci : Pelatihan, Karya Tulis Ilmiah, Karya Tulis Guru

ABSTRACT: The PKM activity was carried out at the Elementary School Institution in Patokan Sub-District of Sysubondo, namely at SDI Al-Abror as a partner. This activity is intended to motivate and train teachers in the school to want to carry out research activities and want to write scientific papers on an ongoing basis. The design mechanism for the implementation of PKM activities is carried out by adopting action research steps consisting of 4 (four) stages, namely: planning, action, observation and evaluation, and reflection. Activities or activities of each stage are (1) Planning, at this stage an initial coordination is carried out between the team proposing a partnership program with a partner school team to identify existing problems, analysis of partner needs, and analysis of potential schools, subsequently arranged training program, (2) Implementation of Actions, Actions in this activity are in the form of Program implementation. The activities carried out in the program implementation include; formation of the Implementation Team, and the implementation of Scientific Writing Workshops, (3) Observation and Evaluation, Observation is carried out on the process of making scientific papers (KTI) and Scientific Journals by partner teachers. The instrument used in the form of field notes, the final stages are (4) Reflections, Reflections carried out on the activities that have been carried out.

Keywords: Training, Scientific Writing, Teacher's Writing

\section{PENDAHULUAN}

Kabupaten Situbondo adalah Kabupaten dengan Tingkat Pendidikan yang masih berada jauh dari kata baik, hal ini dapat dilihat Kabupaten Situbondo masih masuk dalam kategori kabupaten yang berpredikat 3T (tertinggal, terdepan, dan terluar). Pendidikan di 
Kabupaten Situbondo dipengaruhi oleh SDM yang masih jauh tertinggal dari Kabupaten lainnya. Dalam hal ini Mutu dan Kualitas adalah hal yang masih diupayakan oleh pihak terkait. Dalam rangka mengejar ketertinggalan tersebut banyak cara yang telah dilakukan oleh Dinas Pendidikan yaitu diantaranya adalah dengan melakukan diklat kurikulum, sosialisasi Pembelajaran dan pengiriman guru-guru untuk study lanjut. Pada kenyataannya ada permasalahan yang sangat serius, permasalahan yang timbul bukan peningkatan SDM saja tetapi banyak guru-guru yang tidak bisa berkembang dikarenakan kepangkatan mereka belum bisa diajukan, masalah ini sebenarnya bukanlah masalah yang langsung mengena ke tingkat praktis pembelajaran akan tetapi hal ini mempengaruhi aspek psikologis dan materi yang didapat oleh guru tersebut. Pada dasarnya guru-guru yang ada di kecamatan Situbondo rata-rata sudah senior sehingga mereka terkadang mengacuhkan kepangkatan. Hal ini terlihat banyak di Sekolah Dasar di kecamatan Situbondo, berdasarkan hasil wawancara pada tanggal 19 Februari 2019 dengan kepala UPTD Dinas Pendidikan Kecamatan Situbondo yaitu Bapak Samsito, S.Pd beliau menuturkan setidaknya ada Seratusan (100an) lebih guru yang masih belum mengajukan kepangkatan di kecamatan Situbondo. Dari penelusuran yang terjadi adalah poin yang paling sulit dipenuhi adalah pada saat memenuhi kewajiban mengumpulkan KTI sebagai syarat kenaikan jabatan dari IVA ke IV B.

Berdasarkan keputusan Menteri Negara Pendayagunaan Aparatur Negara nomor 84/1993 tentang Jabatan Fungsional Guru dan Angka Kreditnya, serta Keputusan bersama Menteri Pendidikan dan kebudayaan dan Kepala BAKN Nomor 0433/P/1993, nomor 25 tahun 1993 tentang Petunjuk Pelaksanaan Jabatan Fungsional Guru dan Angka Kreditnya, pada prinsipnya bertujuan untuk membina karier kepangkatan dan profesionalisme guru dan Guru-guru. Kebijakan itu di antaranya mewajibkan guru untuk melakukan keempat kegiatan yang menjadi bidang tugasnya, dan hanya bagi mereka yang berhasil melakukan kegiatan dengan baik diberikan angka kredit. Selanjutnya angka kredit itu dipakai sebagai salah satu persyaratan peningkatan karir. Penggunaan angka kredit sebagai salah satu persyaratan seleksi peningkatan karir, bertujuan memberikan penghargaan secara lebih adil dan lebih professional terhadap kenaikan pangkat yang merupakan pengakuan profesi, serta kemudian memberikan peningkatan kesejahteraannya. Dengan terbitnya SK MENPAN No.26/MENPAN/1989 tentang angka kredit bagi jabatan guru, maka berarti kenaikan pangkat guru atau Guru-guru tidak lagi melalui jalur kenaikan pangkat reguler melainkan harus melalui kenaikan pangkat pilihan yaitu kenaikan pangkat struktural dan fungsional setiap 2 (dua) tahun. Hal ini menuntut guru dan Guru-guru harus berusaha mengembangkan dalam melakukan berbagai kegiatan agar memperoleh angka kredit yaitu pengembangan profesi. Pengembangan profesi dilakukan dengan berbagai hal diantaranya dengan melaksanakan kegiatan karya tulis/karya ilmiah di bidang pendidikan. Terutama bagi guru dan Guru-guru pembina (golongan IV/a) agar dapat menduduki jabatan guru pembina tingkat I (golongan IV/b), melaksanakan kegiatan tersebut merupakan keharusan (Juknis Pelaksanaan Angka Kredit 
Bagi Jabatan Guru, dikutip dari Kepmendikbud No.02/O/1995: 44-45). Hal inilah yang menyebabkan masih banyak guru yang hanya berhenti pada golongan IV/a. Terlebih lagi bagi guru dan kepala SD, kegiatan penulisan karya ilmiah masih merupakan suatu permasalahan yang sulit dipecahkan.

Di kecamatan Situbondo khususnya di SD Islam Al-Abror membutuhkan pelatihan KTI dikarenakan, dua sekolah ini kebanyakan dari mereka yang mau naik pangkat ataupun yang belum naik pangkat masih kebigungan untuk membuat KTI (karya tulis ilmiah). Permasalahan diatas tentu adalah masalah klasik dan telah menahun sehingga perlu adanya solusi untuk mengatasinya. SDI Al-Abror adalah sekolah yang memiliki guru yang cukup banyak sehingga program ini akan sangat membantu dalam mengatasi dan mengantisipasi masalah kenaikan Jabatan maupun ketidaktauan KTI yang dijurnalkan. Dengan kegiatan PKM ini diharapkan sekolah mampu meningkatkan kemampuan menulis karya tulis ilmiah (KTI) bagi guru-guru.

Kegiatan PKM ini dilakukan pada Lembaga Sekolah Dasar di Kelurahan Patokan Kec.Situbondo yaitu di SDI Al-Abror sebagai mitra. Kegiatan ini dimaksudkan untuk memotivasi dan melatih para guru di sekolah tersebut agar mau melaksanakan kegiatan penelitian dan mau menulis KTI secara berkesinambungan.

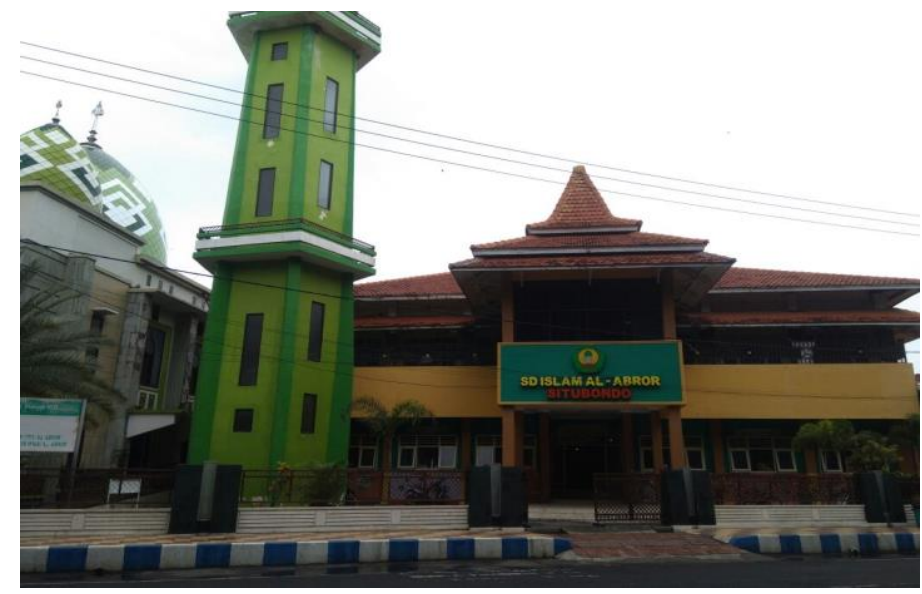

Gambar 1. Lokasi SD Islam Al-Abror

\section{PERMASALAHAN}

Sebagai mitra dalam pelaksanaan PKM ini adalah SD Islam Al-Abror. Berdasarkan analisis situasi dapat teridentifikasi beberapa permasalahan yang dihadapai oleh mitra, yaitu:

(1) Rata-rata setiap Guru belum ada penelitian selama dua semester, baik ganjil maupun genap.

(2) Rendahnya motivasi menulis KTI (karya tulis ilmiah) yang dialami oleh guru-guru.

(3) Pengetahuan para guru terhadap peraturan dan aturan kenaikan pangkat yang masih minim sosialisasi. 
(4) Kurangnya buku- buku maupun jurnal penelitian yang ber ISSN sebagai bahan bacaan.

(5) Pengetahuan Jurnal ber ISSN dan cara untuk memasukkan hasil penelitian masih tidak dipahami oleh guru-guru SD.

(6) Kurangnya sosialisasi KTI dan Penulisan Jurnal bagi guru SD.

\section{Solusi yang ditawarkan.}

Berdasarkan permasalahan yang dihadapi oleh mitra 1 seperti terungkap dalam bab sebelumnya, beberapa alternatif solusi yang dapat ditawarkan adalah sebagai berikut.

1. Pelatihan penulisan karya tulis ilmiah KTI bagi guru-guru di sekolah mitra.

2. Pelatihan penulisan Jurnal Ilmiah bagi guru-guru di sekolah mitra.

3. Pembuatan pojok baca untuk koleksi buku ber ISSN.

4. Sosialisasi aturan Kepangkatan dengan melibatkan dinas Pendidikan kepada sekolah Mitra.

5. Mengikutkan seminar bagi guru yang telah menulis KTI di seminar Nasional maupun regional.

\section{Target Luaran}

Solusi dan Target yang ditawarkan dalam upaya peningkatan menulis KTI bagi para guru di sekolah mitra. Proses desain/perancangan PKM Penulisan KTI dan Jurnal ber ISSN bagi guru mitra adalah sebagai berikut:

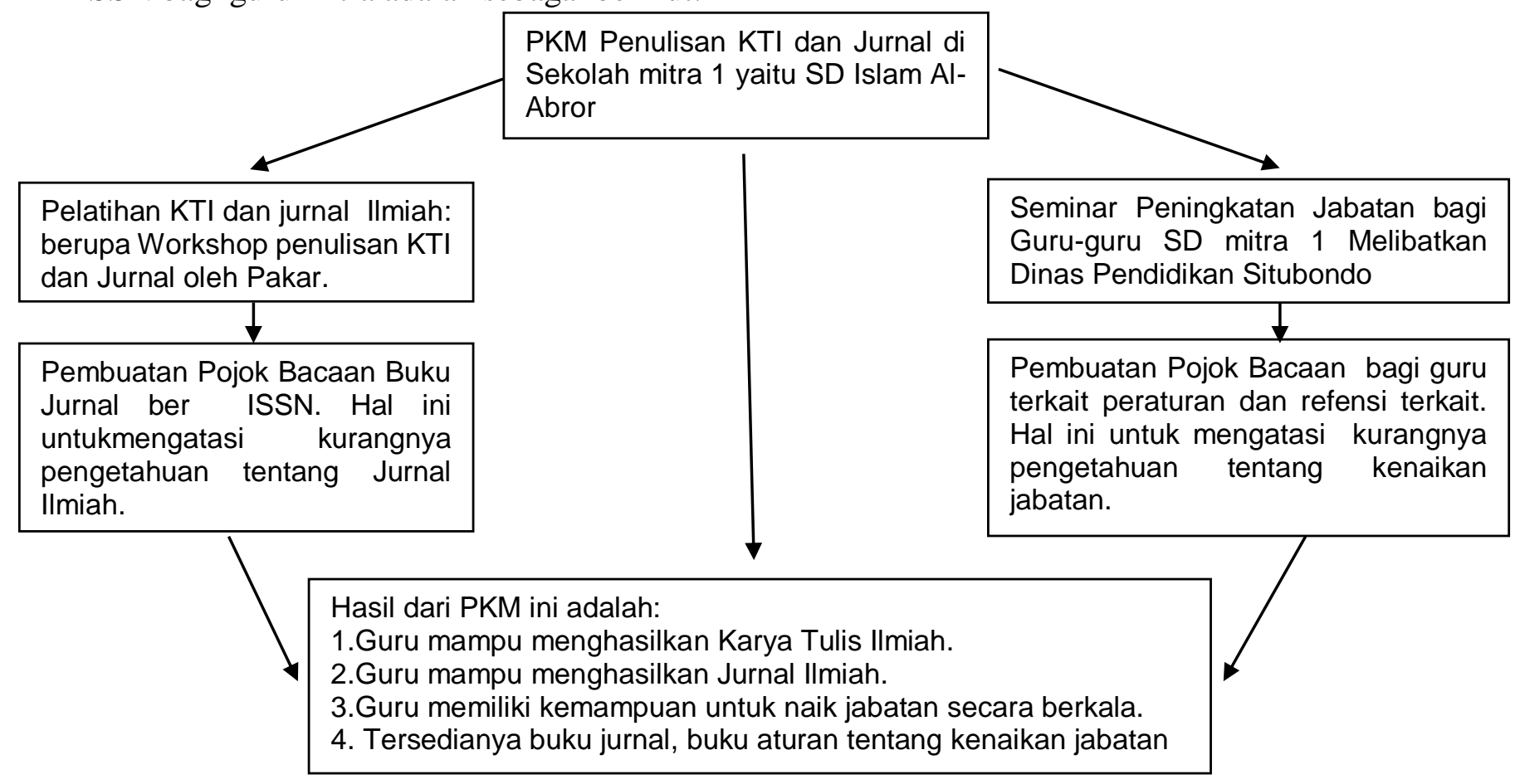

Gambar 2. Desain Program 


\section{METODE PELAKSANAAN}

Rancangan mekanisme pelaksanaan kegiatan PKM ini dilakukan dengan mengadopsi langkah-langkah action research yang terdiri dari 4 (empat) tahapan, yaitu: perencanaan, tindakan, observasi dan evaluasi, dan refleksi. Kegiatan-kegiatan atau aktivitas-aktivitas dari masing-masing tahapan yaitu:

(1) Perencaanaan, pada tahap ini dilakukan koordinasi awal antara tim pengusul program kemitraan bersama tim sekolah mitra untuk mengidentifikasi permasalahan yang ada, analisis kebutuhan mitra, dan analisis potensi sekolah, selanjutnya disusun program pelatihan.

(2) Pelaksanaan Tindakan,

Tindakan dalam kegiatan ini berupa implementasi Program. Kegiatan-kegiatan yang dilakukan dalam implementasi program meliputi; pembentukan Tim Pelaksana, dan pelaksanaan Workshop Karya Tulis Ilmiah,

(3) Observasi dan Evaluasi,

Observasi dilakukan terhadap proses pembuatan karya tulis ilmiah (KTI) dan Jurnal Ilmiah oleh para guru mitra. Instrumen yang digunakan berupa catatan lapangan, tahapan akhir yaitu

(4) Refleksi,

Refleksi dilakukan terhadap kegiatan yang telah dilaksanakan. Hal ini dilakukan semata-mata untuk mengetahui kekurangan-kekurangan atau kelebihan-kelebihan terhadap kegiatan-kegiatan yang telah dilakukan dalam rangka untuk menetapkan rekomendasi terhadap keberlangsungan atau pengembangan kegiatan-kegiatan berikutnya.

\section{PEMBAHASAN}

Tahapan pelaksanaan kegiatan PKM ini dilakukan dengan mengadopsi langkahlangkah action research yang terdiri dari 4 (empat) tahapan, yaitu: perencanaan,tindakan, observasi dan evaluasi, dan refleksi. Pencapaian hasil dari masing-masing tahapan tersebut masing-masing adalah sebagai berikut.

\section{a. Perencanaan}

Kegiatan-kegiatan yang dilakukan pada tahap perencanaan adalah:

\section{(1) Rapat bersama Tim P3M dan peneliti/pelaksana.}

Tim pelaksana diundang untuk mengadakan pertemuan persiapan pelaksanaan dengan melibatkan P3M Universitas Abdurachman Saleh. Tim pelaksana kemudian diberikan pembekalan mengenai maksud, tujuan, rancangan mekanisme program P3M, dan beberapa hal teknis berkaitan dengan metode/teknik pelaksanaan.

\section{(2) Sosialisasi program PKM pada dua sekolah mitra (khalayak sasaran)}

Sosialisasi dilakukan dalam bentuk koordinasi dengan mengundang semua guru, Kepala Sekolah, dan UPTD Dinas Pendidikan Kecamatan Situbondo yang berkenaan dengan program yang akan dilaksanakan. Kegiatan sosialisasi dilakukan oleh Tim Pelaksana didampingi oleh P3M Universitas Abdurachman Saleh. 


\section{(3) Penyusunan program pelatihan}

Berdasarkan hasil identifikasi, hasil analisis permasalahan yang ada, hasil analisis kebutuhan, dan hasil analisis potensi sekolah, selanjutnya disusun program pelatihan. Berdasarkan hasil analaisis situasi, analisis potensi dan kebutuhan sekolah, didapatakan data sejumlah 20 guru yang teridentifikasi sedanag dalam prosese pengajuan kepangkatan dan impassing sertifikasi Guru. Dengan demikian, guru sejumlah 20 orang inilah yang kemudian akan menjadi terget utama PKM Pelatihan Penulisan Karya Tulis Ilmiah Bagi Guru Sekolah Dasar Kecamatan Situbondo Di Sd Islam Al Abror

\section{b. Tindakan}

Tindakan dalam kegiatan ini berupa implementasi Program. Kegiatan-kegiatan yang dilakukan dalam implementasi program adalah (a) pembentukan tim untuk kegiatan Workshop KTI, (b) pelaksanaan Workshop KTI, dengan melakukan kegiatan pelatihan penulisan Karya Tulis Ilmiah dan juga penulisan Jurnal Ilmiah sehingga guru-guru mampu menulis karya tulis ilmiah dan juga jurnal ilmiah. (c) Pembuatan Pojok Bacaan Buku Jurnal ber ISSN. Hal ini untukmengatasi kurangnya pengetahuan tentang Jurnal Ilmiah., (d) pelaksanaan Seminar tentang Seminar Peningkatan Jabatan bagi guru SD mitra yaitu SD Islam Al-Abror yang Melibatkan Dinas Pendidikan Situbondo, e) Pembuatan Pojok Bacaan untuk referensi terkait peraturan dan refensi terkait. Hal ini untukmengatasi kurangnya pengetahuan tentang kenaikan jabatan. Dari jumlah total keseluruhan peserta pelatihan sejumlah 20 guru, semuanya berkesempatan hadir dan tetap mengikuti sampai dengan tahap akhir kegiatan pelatihan, yaitu menyusun satu judul karya tulis penelitian tindakan kelas yang dirumuskan berdasarakan hasil identifikasi masalah yang terjadi pada kelas masing-masing, dan dituangkan dalam bentuk matrik rancangan penelitian, yang kemudian akan dikembangkan menjadi usulan Proposal Penelitian Tindakan Kelas.

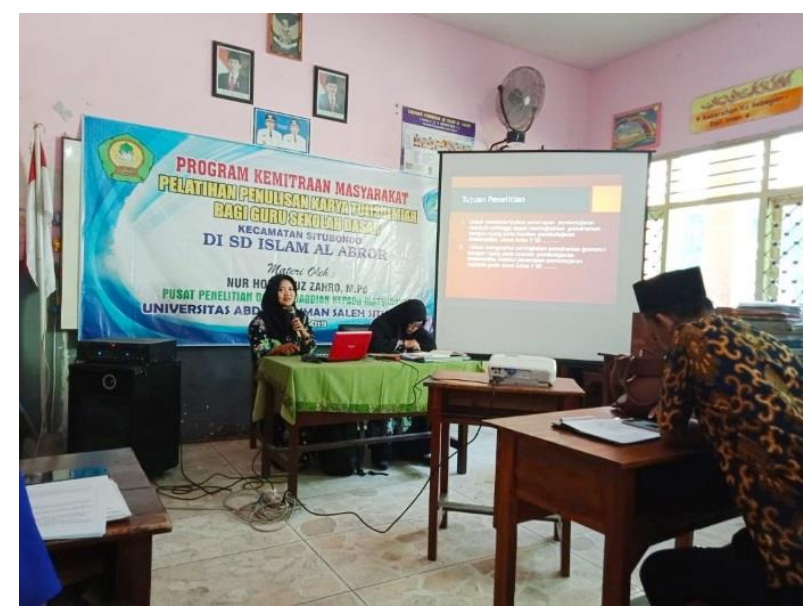

Gambar 3. Pelaksanaan Pelatihan KTI 


\section{c. Observasi dan Evaluasi}

Observasi dilakukan terhadap proses pembuatan karya tulis ilmiah (KTI) dan Jurnal Ilmiah oleh para guru mitra. Instrumen yang digunakan berupa catatan lapangan. Beberapa hal yang diobservasi adalah kendala-kendala, kekurangankekurangan, dan kelemahan-kelemahan yang muncul dalam proses pembuatan di lapangan maupun dalam proses penulisan KTI. Evaluasi dilakukan terhadap kuantitas dan kualitas produk yang dihasilkan. Produk yang dihasilkan dalam kegiatan pelatihan ini adalah Karya Tulis Ilmiah dan Jurnal dari setiap Guru Mitra. Kuantitasnya dilihat dari banyaknya tulisan ilmiah yang dihasilkan oleh para guru, sedangkan kualitasnya terlihat dari banyaknya judul penelitian ilmiah yang mampu masuk jurnal ISSN baik tidak terakreditasi dan terakreditasi.

Berdasarakan hasil observasi dan evaluasi pelaksanaan program, teridentifikasi bahwa para peserta sudah dalam waktu yang relatif lama belum pernah lagi memproduk karya tulis. Oleh karena itu, teknik-teknik untuk menulis dan menyusun karya tulis ilmiah perlu dimaksimalkan kembali pemahamannya. Solusi yang ditawarkan pada saat program pelatihan berjalan adalah, pembimbingan penyusunan matrik penelitian berdasakan hasil review dan identifikasi permasalahan di kelas masing-masing.

Dari hasil pembimbingan tersebut, diperoleh presentase sejumlah $75 \%$ guru sudah berhasil merumuskan rancangan penelitian tindakan kelasnya secara tepat, sdangkan $25 \%$ sisanya masih perlu diadakan prbaikan dan pemantapan.

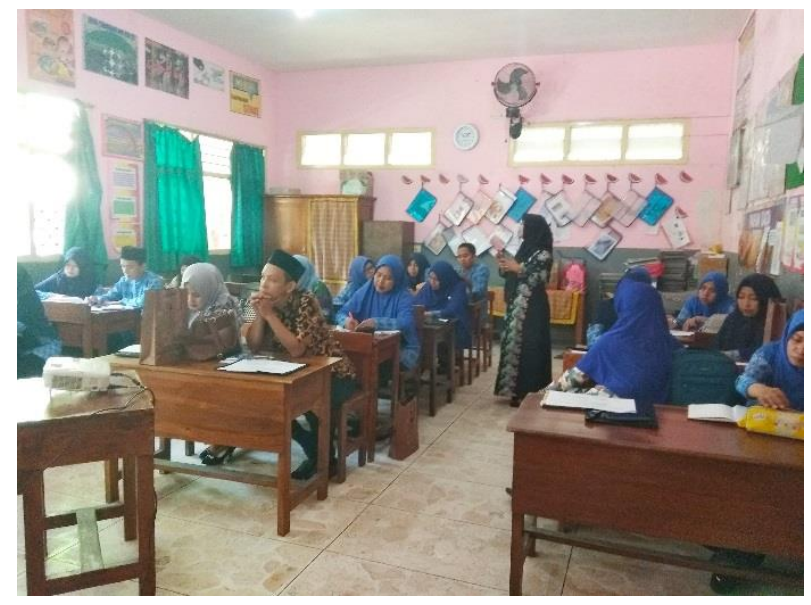

Gambar 4. Proses Pembimbingan Penyusunan KTI

\section{d. Refleksi}

Refleksi dilakukan terhadap kegiatan yang telah dilaksanakan. Hal ini dilakukan semata-mata untuk mengetahui kekurangan-kekurangan atau kelebihankelebihan terhadap kegiatan-kegiatan yang telah dilakukan dalam rangka untuk menetapkan rekomendasi terhadap keberlangsungan atau pengembangan kegiatankegiatan berikutnya. 
Berdasaraan hasil refleksi diperoleh rumusan permasalahan dan kebutuhan pada SDM guru di sekolah mitra antara lain;

a) kurangnya informasi terkait prosedur usulan kepangkatan

b) guru terlalu fokus mengajar sehingga waktu yang diperlukan untuk mnulis sulit dilakukan

c) kurangnya buku-buku maupun jurnal dan referensi sebagai bahan bacaan sehingga pemahaman tentang karya tulis ilmiah masih belum maksimal

\section{Luaran yang Dicapai}

Adapun target luaran yang dicapai dari PKM Pelatihan Penulisan Karya Tulis Ilmiah Bagi Guru di sekolah mitra adalah sebagai berikut:

1) Guru-guru mampu menulis KTI dan Jurnal Ilmiah. Berdasarkan hasil evaluasi, sudah 75\% guru mampu merumuskan usulan penelitian tindakan kelas berdasarkan hasil identifikasi permasalahan di kelas

2) Adanya Bahan bacaan yang berisi Jurnal-jurnal Ber ISSN yang mampu dibaca oleh. Guru dengan menciptakan pojok bacaan khusus Jurnal-jurnal.

3) Adanya produk KTI dari guru-guru mitra yang mampu diikutkan seminar Nasioanal maupun Regional.

4) Terciptanya kelompok atau grup guru-guru bidang muatan dan mata pelajaran untk tim KTI di sekolah; (a) Kelompok Guru Mapel, (b) Kelompok Guru Kelas.

\section{KESIMPULAN DAN SARAN \\ Kesimpulan}

Pelaksanaan Dharma Pengabdian dalam wujud Program Kemitraan Masyarakat Pelatihan Penulisan Karya Tulis Ilmiah Bagi Guru Sekolah Dasar Kecamatan Situbondo Di Sd Islam Al Abror telah memperoleh hasil yaitu peningkatan kemampuan guru dalam merumuskan usulan penelitian tindakan kelas berdasarkan hasil identifikasi permasalahan di kelas. Dimana dari keseluruhan jumlah peserta dalam target program ini telah diperoleh $75 \%$ peserta yang sudah berhasil merumuskan krya tulisnya secara tepat. Dengan demikian, produk KTI dari guru-guru mitra ini dapat diikutsertakan dalam seminar Nasioanal maupun Regional, serta sudah bisa dipublish dalam jurnal.

Hasil lain yang diperoleh yaitu terbentunya kelompok atau grup guru-guru bidang muatan dan mata pelajaran untk tim KTI di sekolah; (a) Kelompok Guru Mapel, (b) Kelompok Guru Kelas. Kelompok ini nantinya akan secara berkesinambungan mencoba terus saling berkoordinasi untuk tetap mnciptakan inovasi pembelajaran yang nantinya akan dituangkan dalam bentuk karya tulis penelitian tindakan kelas. 


\section{Saran}

1. Kegiatan Dharma pengabdian ini memerlukan waktu yang cukup lama, akan tetapi program ini masih trbentur dengan permaslahan dana operasional dan durasi waktu pelaksaan program demi tercapainya target yang maksimal.

2. PKM Pelatihan Penulisan Karya Tulis Ilmiah Bagi Guru Sekolah Dasar Kecamatan Situbondo Di SD Islam Al Abror memerlukan variasi referensi jurnal yang bisa menjadi bahan penunjang referensi bagi guru pada sekolah mitra.

3. Program ini memerlukan adanya dukungan kebijakan agar kegiatan ini dapat terus berkembang secara berkesinambungan

\section{DAFTAR PUSTAKA}

Arikunto, S. 2007. Prosedur Penelitian Suatu Pendekatan Praktik. Jakarta: PT. Rineka Cipta

Kunandar.2011. Langkah Mudah Penelitian Tindakan Kelas Sebagai Pengembangan Profesi Guru.Jakarta: Raja Wali Pres.

Mulyasa, H.E. 2009. Praktek Penelitian Tindakan Kelas. Bandung: Rodakarya.

Sugiyono. 2009. Metode Penelitian Kuantitatif Kualitatif dan R\&D. Bandung : Alfabeta. 
Volume 3, Nomor 2, September 2019 